\title{
ANALISIS KESULITAN BELAJAR MENULIS PADA SISWA KELAS III SEKOLAH DASAR NEGERI 1 RANTAU SELAMAT KEC. RANTAU SELAMAT KAB. ACEH TIMUR.
}

\author{
Irmayani Putri
}

\begin{abstract}
Abstrak
Penelitian ini berjudul "Analisis Kesulitan Belajar Menulis pada Siswa Kelas III Sekolah Dasar Negeri 1 Rantau Selamat Kec. Rantau Selamat Kabupaten Aceh Timur". Penelitian ini mengambil permasalahan mengenai kesulitan belajar menulis pada siswa kelas III di sekolah dasar. Kesulitan belajar menulis sering disebut juga disgrafia. Kesulitan belajar menulis yang berat disebut juga agrafia. Disgrafia menunjuk pada adanya ketidakmampuan mengingat cara membuat huruf atau simbol-simbol matematika. Disgrafia sering dikaitkan dengan kesulitan belajar membaca atau disleksia karena kedua jenis kesulitan tersebut sesungguhnya saling terkait. Berdasarkan identifikasi masalah, maka masalah umum yang muncul dan perlu ditindaklanjuti adalah dengan mengimplementasikan model pembelajaran menulis sebagai upaya untuk meningkatkan kemampuan menulis siswa. Rumusan masalah dalam penelitian ini adalah seperti apakah kesulitan menulis yang dialami siswa dan faktor-faktor apakah yang menyebabkan siswa sulit menuis. Penelitian ini bertujuan untuk mengetahui atau mendeskripsikan kemampuan siswa dalam menulis dengan menggunakan berbagai model menulis. Secara lebih khusus tujuan penelitian ini untuk mendeskripsikan kemampuan menulis siswa SD kelas III dan mengetahui faktor-faktor yang menyebabkan siswa sulit menulis.
\end{abstract}

Kata Kunci: analisis, kesulitan, belajar, menulis, disgrafia, agrafia

\section{A. PENDAHULUAN}

Sekolah sebagai lembaga pendidikan merupakan salah satu modal siswa untuk memajukan pembangunan, karena lembaga pendidikan bertujuan mengembangkan pengetahuan dan potensi yang dimiliki siswa. Lembaga pendidikan sangat berperan berkaitan dengan pentingnya meningkatkan prestasi belajar siswa terhadap kualitas pendidikan, salah satunya pada pengajaran bahasa Indonesia yang bertujuan agar siswa terampil berbahasa; terampil menyimak, berbicara, membaca dan terampil menulis (Tarigan, 1987: 2).

Kemampuan menulis tidak berdiri sendiri, melainkan saling berhubungan dengan kemampuan lain, yaitu membaca, berbicara dan menyimak. Baik menulis maupun keterampilan lainnya memiliki fungsi 
untuk manusia dalam mengkomunikasikan pesan melalui bahasa.

Pesan yang menjadi isi sebuah tulisan itu dapat berupa ide, kemauan, keinginan, perasaan, ataupun informasi tentang sesuatu. Pada dasarnya setiap orang memiliki potensi untuk menulis namun tidak setiap orang dapat menyampaikan pesan melalui tulisan. Siswa di sekolah dasar memiliki potensi yang sama untuk menulis, namun tidak setiap siswa memiliki keterampilan menulis yang sama.

Halliday dalam Tompkins (1994) menyatakan"Learning language, learning about language, and learning throughlanguage as the three component in the langage arts." Untuk itu, menurut Tompkins (1994), "These components can be rephrases to describe the role of writing in the elementary grades: (1) learning to write; (2) learning about written language; (3) learning through writing." Jadi, fokus pembelajaran menulis di SD adalah (1) belajar untuk menulis, (2) belajar tentang tulisan, dan(3) belajar melalui tulisan.

Berdasarkan hasil tulisan siswa yang penulis identifikasi, ternyata siswa tersebut mempunyai kesulitan-kesulitan dalam memproduksi tulisan grafemis sebagai berikut:

1) tidak bisa menulis $F, f, V, v$, $Q, q, X, x, Z$,
2) ada tulisan grafemis yang tertukar seperti $d$ menjadi $b$ atau sebaliknya; $m$ menjadi $n$ atau sebaliknya;

3) Adanya pengurangan tulisan grafemis ketika guru mendiktekan tulisan $n g$, ny, menjadi $g$ dan $y$ misalnya pada kata dengan $\square$ degan, misalnya $\square$ misalya;

4) Adanya penambahan tulisan grafemis $h, y$, misalnya saya sayah, ia $\quad \square \quad$ iya Berdasarkan hasil wawancara, faktor-faktor penyebab ketidakmampuan menulis tersebut disebabkan oleh:

1) kurangnya (jarang dipakai) frekuensi kemunculan tulisan grafemis seperti $V, v, Q$, $q, X, x, Z, z$, sehingga mereka ada yang tidak bisa menulis dan ada pula yang tertukar dengan tulisan grafemis lain seperti $V$ dengan $P, Q$ dengan $K, Z$ dengan $J$ dan $S, X$ dengan $S$ ( pada kata, Xilofon dan Xilem).

2) kemiripan tulisan grafemis seperti $d$ menjadi $b$ atau sebaliknya, $m$ menjadi $n$ atau sebaliknya;

3) secara psikologis kurang konsentrasi dalam menyimak, 
4) faktor lain yang tidak kalah penting ialah minimnya perhatian orang tua terhadap siswa sehingga motivasi belajar mereka kurang.

Atas dasar itulah penulis memilih judul Analisis Kesulitan Belajar Menulis pada Siswa Kelas III Sekolah Dasar Negeri 1 Rantau Selamat Kec. Rantau Selamat Kab. Aceh Timur.

Menelisik rumusan masalah di atas, maka penelitian ini bertujuan untuk mengetahui atau mendeskripsikan kemampuan siswa dalam menulis dengan menggunakan berbagai model menulis. Secara lebih khusus tujuan penelitian ini dapat dirinci sebagai berikut:

1) mendeskripsikan kemampuan menulis siswa SD kelas III;

2) mengetahui faktor-faktor yang menyebabkan siswa sulit menulis.

Secara teoretis, penelitian ini bermanfaat sebagai uji empirik terhadap strategi menulis di sekolah dasar dengan berbagai macam model menulis.

Secara praktis, hasil penelitian ini bermanfaat khususnya bagi para guru sekolah dasar, lembaga LPTK, dalam hal ini PGSD, dan para pengembang kurikulum bahasa Indonesia sebagai upaya meningkatkan kemampuan siswa dalam menulis.

\section{B. TINJAUAN PUSTAKA}

Pada bagaian ini akan dijelaskan ihwal kesulitan belajar menulis. Penjelasan lebih rincinya di bawah ini.

Abdurrahman (2003: 6) menjelaskan bahwa definisi kesulitan belajar pertama kali dikemukakan oleh The United States Office of Education (USOE) pada tahun 1977 yang dikenal dengan Public Law (PL) 94-142, yang hampir identik dengan definisi yang dikemukakan oleh The National Advisory Committee on Handicapped Children pada tahun 1967. Definisi tersebut seperti dikutif oleh Hallahan, Kauffman, dan Llioyd (1985: 14) seperti berikut ini.

Kesulitan belajar khusus adalah suatu gangguan dalam satu atau lebih dari proses psikologis dasar yang mencakup pemahaman dan penggunaan bahasa ujaran atau tulisan. Gangguan tersebut mungkin menampakkan diri dalam bentuk kesulitan mendengarkan, berpikir, berbicara, membaca, menulis, mengeja, atau berhitung. Batasan tersebut mencakup kondisi-kondisi seperti gangguan perceptual, luka pada otak, disleksia, dan afasia perkembangan. Batasan tersebut tidak mencakup anak-anak yang memiliki problema belajar yang penyebab utamanya berasal dari adanya hambatan dalam penglihatan, pendengaran, atau motorik, hambatan karena tunagrahita, karena gangguan emosional, atau karena 
kemiskinan lingkungan, budaya, atau ekonomi.

Meskipun definisi USOE merupakan definisi resmi yang digunakan oleh pemerintah Amerika Serikat, tetapi banyak kritik yang diarahkan pada definisi tersebut karena berbagai alasan.

$$
\text { Lovitt }
$$

(1988:

mengemukakan lima macam kriktik, yaitu (1) berkenaan dengan penggunaan istilah "anak", (2) proses psikologi dasar, (3) pemisahan mengeja dari ekspresi pikiran dan perasaan secara tertulis, (4) adanya berbagai kondisi yang digabungkan menjadi satu, dan (5) pernyataan bahwa kesulitan belajar dapat terjadi bersamaan dengan kondisikondisilain. Jika kajian tentang kesulitan belajar tersebut mencakup orang dewasa maka akan terjadi suatu perdebatan yang luas dan terjadi kesalahpahaman.

Sebagai konsekuensi dari adanya berbagai kritik terhadap definisi PL 94-142 tersebut maka The National Joint Committee for Learning Disabilities (NJCLD) mengemukakan definisi sebagaiberikut. Kesulitan belajar menunjuk pada kelompok kesulitan yang dimanifestasikan dalam bentuk kesulitan yang nyata dalam kemahiran dan penggunaan kemampuan mendengarkan, bercakap-cakap, membaca, menulis, menalar, atau kemampuan dalam bidang studi matematika. Gangguan tersebut intrinsik dan diduga disebabkan oleh adanya disfungsi sistem saraf pusat. Meskipun suatu kesulitan belajar mungkin terjadi bersamaan dengan adanya kondisi lain yang menganggu (misalnya gangguan sensoris, tunagrahita, hambatan sosial, dan emosional) atau berbagai pengaruh lingkungan (misalnya perbedaan budaya, pembelajaran, yang tidak tepat, faktorfaktor psikogenetik), berbagai hambatan tersebut bukan penyebab atau pengaruh langsung (Hammil et al., 1981: 336).

Meskipun definisi yang dikemukakan oleh NJCLD memiliki kelebihan-kelebihan bila dibandingkan dengan definisi yang dikemukakan PL 94- 142, the Board of the Association for Children and Adulth with Learning Disabities (ACALD) tidak menyetujui definisi tersebut, dan karena itu mereka mengemukakan definisi seperti dikutif oleh Lovitt (1989: 7) berikut ini.

Kesulitan belajar khusu adalah suatu kondisi kronis yang diduga bersumber neurologis yang secara selektif menganggu perkembangan, integrasi, dan/atau kemampuan verbal dan/atau nonverbal. Kesulitan belajar khusus tampil sebagai suatu kondisi ketidakmampuan yang nyata pada orang-orang yang memiliki inteligensi rata-rata hingga superior yang memiliki sistem sensoris yang cukup, dan kesempatan untuk belajar yang cukup pula. Berbagai kondisi 
tersebut bervariasi dalam perwujudan dan derajatnya.

Kondisi tersebut dapat berpengaruh terhadap harga diri, pendidikan, sosialisasi, dan/atau aktivitas kehidupan sehari-hari sepanjang kehidupan.

Dari ketiga definisi kesulitan belajar di atas, di samping memiliki perbedaan juga memiliki titik-titik kesamaan, yaitu (1) kemungkinan adanya disfungsi neurologis, (2) adanya kesulitan dalam tugas-tugas akademik, (3) adanya kesenjangan antara prestasi dengan potensi, dan (4) adanya pengeluaran dari sebabsebab lain.

Ketiga definisi juga mengindikasikan bahwa kesulitan belajar dapat berwujud sebagai suatu kekurangan dalam satu atau lebih bidang akademik, baik dalam mata pelajaran yang spesifik seperti membaca, menulis, matematika, dan mengeja; atau dalam berbagai keterampilan yang bersifat lebih umum seperti mendengarkan, berbicara, dan berpikir. Definisi yang dikemukakan oleh ACALD menyatakan bahwa kesulitan belajar dapat muncul dalam bentuk penyesuaian sosial atau vokasional, keterampilan kehidupan sehari-hari, atau harga diri. Ketiga definisi mengemukakan bahwa anak berkesulitan belajar memperoleh prestasi belajar jauh di bawahpotensi yang dimilikinya. Potensi umumnya diukur dengan tes inteligensi, biasanya menggunakan WISC-R
(Weschsler Intelligence Scale for Children-Riviced). Prestasi belajar umumnya diukur dengan tes prestasi belajar.

Menurut Abdurrahman (2003: 9) di Indonesia belum ada definisi yang baku tentang kesulitan belajar. Para guru umumnya memandang semua siswa yang memperoleh prestasi belajar rendah disebut siswa berkesulitan belajar. Dalam kondisi seperti itu, kiranya dapat dipertimbangkan untuk mengadopsi definisi yang dikemukakan oleh ACALD untuk digunakan dalam dunia pendidikan di Indonesia.

Dari ketiga definisi kesulitan belajar di atas, peneliti mengindikasikan bahwa kesulitan belajar yang dialami subjek yang diteliti, berwujud sebagai suatu kekurangan di bidang akademik dalam mata pelajaran yang spesifik yaitu kesulitan dalam menulis.

\section{a. Ihwal Menulis}

Djuanda dkk. (2006: 297) mengemukakan bahwa menulis berhubungan dengan membaca, mewicara, dan menyimak. Baik menulis, membaca, mewicara, maupun menyimak memilikifungsi untuk manusia dalam mengomunikasikan pesan melalui bahasa.

Lerner (1985: 413) mengemukakan bahwa menulis adalah menuangkan ide dalam suatu bentuk visual. Soemarmo Markam 
(1989: 7) menjelaskan bahwa menulis adalah mengungkapkan bahasa dalam bentuk simbol gambar. Menulis adalah sebagai suatu aktivitas kompleks yang mencakup gerakan lengan, tangan, jari, dan mata secara terintegrasi.

Menulis juga terkait
dengan pemahaman bahasa
dan kemampuan berbicara
(Abdurrahman, 2003: 224).
Tarigan $(1986: 21)$
mendefinisikan menulis
sebagai melukiskan lambang-
lambang grafis dari bahasa
yang dipahami oleh
penulisnya maupun orang-
orang lain yang
menggunakan bahasa yang
sama dengan penulis tersebut.
Menurut Poteet seperti
dikutip oleh Hargrove dan
Poteet (1984: 239), menulis
merupakan penggambaran
visual tentang pikiran,
perasaan, dan ide dengan
menggunakan simbol-simbol
sistem bahasa penulisnya
untuk keperluan komunikasi
atau mencatat.

Dari beberapa definisi tentang menulis yang dikemukakan dapat disimpulkan bahwa "menulis merupakan salah satu komponen sistem komunikasi yang menggambarkan pikiran, perasaan, dan ide ke dalam bentuk lambanglambang bahasa grafis dan dilakukan untuk keperluan mencatat dan mengomunikasikan pesan melalui bahasa".

\section{b. Ihwal Kesulitan Belajar Menulis}

Pada esensinya, setiap anak didik mempunyai beberapa kesulitan dalam belajar. Pada tingkat dasar, khususnya mata pelajaran bahasa Indonesia, dalam hal ini keterampilan berbahasa, anak didik tidak sedikit yang mengalami kesulitan belajar baik, menyimak, membaca, berbicara, atau menulis. Kasus yang ditangani oleh penulis merupakan kasus anak yang mempunyai kesulitan dalam menulis.

Abdurrahman (2003: 225) menjelaskan bahwa proses belajar menulispada hakikatnya suatu proses neurofisiologis. Russel dan Wanda (1986: 16-21) mengemukakan adanya pembagian otak ke dalam empat Lobus yakni: (1) lobus frontalis, (2) lobus parietalis, (3) temporalis, dan (4) lobus occipitalis. Lobus frontalis terletak di bagian depan, dilindungi oleh tulang dahi. Fungsi lobus frontalis adalah sebagai pusat pengertian, koordinasi motorik, dan yang berhubungan dengan watak dan tabiat. Lobus perietalis terletak di bagian atas, dilindungi oleh tulang-tulang ubun. Fungsi lobus perietalis adalah untuk menerima dan menginterpretasikan rangsangan sensoris, kinestetis, orientasi ruang, penghayatan tubuh (body emage), dan taktil lobus temporalis terletak pada bagian samping, dilindungi oleh tulang pelipis. Adapun fungsi lobus 
temporalis adalah sebagai pusat pengertian pembicaraan, pendengaran, asosiasi pendengaran, memori, pengecap, dan penciuman. Lobus occipitalis terletak di bagian belakang, dilindungi oleh tulang belakang kepala. Fungsi lobus occiptalis adalah sebagai pusat penglihatan dan asosiasi penglihatan.

Pada saat menulis akan terjadi peningkatan aktivitas pada susunan saraf pusat dan bagianbagian organ tubuh. Rangsangan dari lingkungan diterima oleh alat indra dan selanjutnya diteruskan ke susunan saraf pusat melalui ke cortex di daerah lobus occipitalis, lobus temporalis, lobus parietalis, dan lobus frontalis; kemudian kembali ke saraf-saraf spinal yang keluar dari sumsum tulang belakang. Saraf-saraf spinal tersebut selanjutnya meneruskan rangsangan motorik

\section{METODE DAN DESAIN PENELITIAN}

Penelitian ini bersifat deskriptif kualitatif dengan menggunakan metode penelitian studi kasus terhadap siswa kelas III SDN 1 Rantau Selamat Kec. Rantau Selamat Kab. Aceh Timur, Tahun Ajaran 2016/2017.

Desain penelitian ini menggunakan desain kasus kelompok. Secara keseluruhan, desain studi kasus bisa dibenarkan dalam kondisi-kondisi tertentu yakni (a) kasus tersebut mengetengahkan suatu uji penting tentang teori yang ada, (b) merupakan suatu peristiwa melalui sistem piramidal dari otak untuk selanjutnya berhubungan dengan sumsum tulang belakang yang berfungsi untuk mengaktifkan otot-otot lengan, tangan, dan jari-jari untuk menulis sebagai respons terhadap rangsangan yang diterima.

Pelajaran menulis mencakup

(1) menulis dengan tangan, (2) mengeja, dan (3) menulis ekspresif (Lovitt, 1989: 225). Menulis dengan tangan disebut juga menulis permulaan; dan karena menulis terkait erat dengan membaca, maka pelajaran membaca dan menulis di kelaskelas permulaan sekolah dasar sering disebut juga pelajaran membaca dan menulis permulaan. Mengenai menulis ekspresif, Hallahan, Kauffman, dan Lloyd (1985: 235) menyebutnya mengarang atau komposisi.

yang langka atau unik, atau (c) berkaitan dengan tujuan penyingkapan (Yin, 2002).

Tahap penting dalam pendesainan dan penyelenggaraan kasus kelompok adalah menentukan unit analisis kasus itu sendiri. Definisi yang operasional dibutuhkan, dan beberapa tindakan pencegahan harus diambil sebelum kesepakatan penuh keseluruhan studi kasus tersebut tercapai guna meyakinkan bahwa kasus tersebut memang relevan dengan isu dan 
pertanyaan-pertanyaan fokus

penelitiannya.

Langkah-langkah dalam penelitian ini antara lain:

1) melakukan

pengamatan/observasi;

2) melakukan wawancara dengan guru dan siswa;

3) menyuruh para siswa membuat karangan bebas sebagai prates;

4) mengidentifikasi kesalahankesalahan dalam karangan tersebut;

5) memberi perlakuan sebanyak tiga kali pertemuan kepada siswa;

6) menyuruh siswa membuat karangan sebagai pascates.

Subjek penelitian adalah siswa kelas III Sekolah Dasar Negeri 1 Rantau Selamat Kec. Rantau Selamat Kab. Aceh Timur berjumlah 35 siswa dengan rincian 18 siswa perempuan dan 17 siswa laki-laki. Adapun mayoritas pekerjaan orang tua sebagai buruh tani.

Intrumen penelitian ini menggunakan instrumen informal yang dikembangkan oleh Poteet (Lovitt, 1989:225). Instrumen berupa daftar cek untuk mengukur kemampuan siswa dalam menulis permulaan.

\section{PEMBAHASAN}

Berdasarkan hasil tulisan siswa yang penulis identifikasi, ternyata siswa tersebut mempunyai kesulitan- kesulitan dalam memproduksi tulisan grafemis sebagai berikut:

1) tidak bisa menulis $F, f, Q, q$, $X, x, Z$,

2) ada tulisan grafemis yang tertukar seperti $d$ menjadi $b$ atau sebaliknya; $m$ menjadi $n$ atau sebaliknya;

3) Adanya pengurangan tulisan grafemis ketika guru mendiktekan tulisan $n g$, $n y$, menjadi $g$ dan $y$ misalnya pada kata dengan $\square$ degan, misalnya $\square$ misalya;

4) Adanya penambahan tulisan grafemis $h, y$, misalnya saya $\square$ sayah, ia $\square$ iya

Berdasarkan hasil wawancara, faktor-faktor penyebab ketidakmampuan menulis tersebut disebabkan oleh:

1) kurangnya (jarang dipakai) frekuensi kemunculan tulisan grafemis seperti $Q, q, X, x, Z$, $z$, sehingga mereka ada yang tidak bisa menulis dan ada pula yang tertukar dengan tulisan grafemis lain seperti $Q$ dengan $K, Z$ dengan $J$ dan $S$, $X$ dengan $S$ ( pada kata, Xilofon dan Xilem).

2) kemiripan tulisan grafemis seperti $d$ menjadi $b$ atau sebaliknya, $m$ menjadi $n$ atau sebaliknya;

3) secara psikologis kurang konsentrasi dalam menyimak,

4) faktor lain yang tidak kalah penting ialah minimnya perhatian orang tua terhadap 
siswa sehingga motivasi belajar mereka kurang.

Kemampuan menulis tidak berdiri sendiri, tetapi saling berhubungan dengan kemampuan lain, yaitu membaca, berbicara, dan menyimak. Baik menulis maupun keterampilan lainnya memiliki fungsi untuk manusia dalam mengkomunikasikan pesan melalui media bahasa. Pesan yang menjadi isi sebuah tulisan itu dapat berupa ide, kemauan, keinginan, perasaan, maupun informasi tentang sesuatu.

Pada dasarnya setiap orang memiliki potensi untuk menulis, namun tidak setiap orang dapat menyampaikan pesan melalui tulisan. Siswa di sekolah dasar memiliki potensi yang sama untuk menulis, namun tidak setiap siswa memiliki keterampilan menulis yang sama. Misalnya, siswa yang dijadikan kasus ini, mendapat kesulitan dalam keterampilan menulis.

Berdasarkan hasil tulisan siswa yang penulis identifikasi, ternyata siswa tersebut mempunyai kesulitan-kesulitan dalam memproduksi tulisan grafemis sebagai berikut:

1) tidak bisa menulis $F, f, Q, q$, $X, x, Z$,

2) ada tulisan grafemis yang tertukar seperti $d$ menjadi $b$ atau sebaliknya; $m$ menjadi $n$ atau sebaliknya;

3) Adanya pengurangan tulisan grafemis ketika guru mendiktekan tulisan $n g$, $n y$, menjadi $g$ dan $y$ misalnya pada kata dengan $\square$ degan, misalnya $\square$ misalya;

4) Adanya penambahan tulisan grafemis $h, y$, misalnya saya $\square$ sayah, ia $\square$ iya

Faktor-faktor penyebab ketidakmampuan menulis tidak lepas dari kemampuan keterampilan lain - Tisalnya secara psikologis kur 11 isentrasi dalam menyimak, dan siswa tersebut jarang berbicara karena pemalu. Kurang memahami suatu bacaan yang telah dibacanya. Dalam penyusunan ide kurang diksi yang dikuasainya. Juga kurang motivasi belajar dari orang tuanya, serta kurangnya fasilitas belajar di rumah. Masalah-masalah yang dialami siswa masih mungkin untuk diatasi. Adapun alternatif pemecahan yang mungkin untuk ditempuh adalah sebagai berikut.

1) Siswa harus sering diberi motivasi belajar baik oleh guru maupun orang tuanya dengan bersabar

2) Siswa diberi buku bacaan yang menarik dan di dalam buku tersebut terdapat frekuensi yang sering memunculkan huruf-huruf yang jarang ditemui seperti $F$, $f, Q, q, X, x, Z, z$.

3) Diberi motivasi gemar membaca karena dengan banyak membaca akan bertambah penguasaan hurufnya. 
4) Guru maupun orang tuanya harus memberi stimulus agar siswa dapat berani berbicara dan mendapatkan jati dirinya.

5) Siswa harus banyak latihan menulis.

Solusi yang diberikan kepada siswa dengan cara memberikan perlakuan yaitu dengan cara remedial. Adapun jenis pengajaran remedial menulis permulaan adalah berikut ini.

1) Pembelajaran dalam proses menulis.

a. Memberi kesempatan kepada anak untuk banyak menulis.

Anak berkesulitan belajar yang menulis rata-rata hanya selama 10 menit dalam sehari. Dari ratarata menulis seperti itu hendaknya ditingkatkan sedikit demi sedikit, sehingga menjadi 50 menit setiap hari, empat hari dalam seminggu.

b. Menempatkan anak dalam suasana kehidupan yang gemar menulis.

Guru hendaknya menciptakan suasana kelas yang menggemari menulis melalui interaksi koperatif dalam menyelesaikan pekerjaanpekerjaan menulis. Berbagai bahan dan buku hendaknya ditempatkan di suatu tempat yang memudahkan anak untuk menggunakannya sehingga menulis tidak lagi merupakan suatu tugas tetapi sudah menjadi kebutuhan anakanak.

c. Biarkan anak memilih topik tulisannnya sendiri. Belajar menulis akan sangat berhasil jika anak diberi kebebasan untuk memilih topik yang hendak ditulis. Jika anak membutuhkan lebih banyak informasi tentang apa yang hendak ditulis, guru hendaknya menyediakan sumber informasi yang cukup.

d. Model penulisan dan berpikir strategis.

Guru memberikan model proses kognitif yang terlibat dalam penulisan.

e. Mengembangkan berpikir reflektif.

Anak disuruh menulis sesuai dengan standar kebenaran guru. Pengajaran dapat perluas dengan memberikan kepada anak kebebasan untuk mengemukakan pikiran dan perasaannya, yang mungkin berbeda dari standar kebenaran guru.

f. Transfer kepemilikan dan kontrol penulisan siswa. 
Tujuan proses penulisan adalah transfer kepemilikan dan mengontrol siswa. Pada saat siswa belajar untuk menginternalisasikan yang diajarkan oleh guru, mereka harus secara sedikit demi sedikit mengambil tanggung jawab atas tulisan mereka sendiri dan harus mampu bekerja tanpa pengarahan guru.

2) Memberikan motivasi secara bertingkat.

Agar siswa berani mengekspresikan pikiran dan perasaannya dalam bentuk tulisan penulisan hendaknya diberikan secara bertingkat. Penilaian diarahkan pada ide dan teknik penulisannya. Bagi anak yang masih banyak melakukan kesalahan, penilaian diarahkan pada salah satu keterampilan, misalnya pemakaian huruf kapital atau penggunaan tanda baca saja.

3) Tulisan pribadi dan tulisan fungsional.

Tulisan pribadi bertujuan untuk mengembangkan ide dan mengekspresikannya ke dalam bentuk tulisan. Dalam tulisan fungsional tujuannya adalah agar orang lain memahami isi tulisan, dan karena itu teknik penulisannya harus sempurna.

4) Memberikan masukan sebanyakbanyaknya.

Siswa dapat menulis dengan baik, mereka memerlukan bahan untuk ditulis. Pembicaraan guru dengan siswa tentang pengalaman mereka dapat meningkatkan siswa untuk menulis permulaan.

5) Melengkapi kalimat.

Tugas melengkapi kalimat merupakan suatu metode menulis yang bermanfaat. Guru menyediakan kalimat yang tidak lengkap dan siswa diminta untuk melengkapi kalimat tersebut.

6) Menggabungkan berbagai kalimat.

Menulis beberapa kalimat yang terpisah-pisah tetapi kalimat-kalimat tersebut dapat disusun menjadi suatu cerita. Selanjutnya anak diminta untuk menyusun kalimat- kalimat tersebut menjadi suatu cerita yang logis dan sistematis.

Berdasarkan hasil wawancara, faktor-faktor penyebab ketidakmampuan menulis tersebut disebabkan oleh:

1) kurangnya (jarang dipakai) frekuensi kemunculan tulisan grafemis seperti $Q, q, X, x, Z$, $z$, sehingga mereka ada yang tidak bisa menulis dan ada 
pula yang tertukar dengan tulisan grafemis lain seperti $Q$ dengan $K, Z$ dengan $J$ dan $S$, $X$ dengan $S$ ( pada kata, Xilofon dan Xilem).

2) kemiripan tulisan grafemis seperti $d$ menjadi $b$ atau sebaliknya, $m$ menjadi $n$ atau sebaliknya;

3) secara psikologis kurang konsentrasi dalam menyimak,

4) faktor lain yang tidak kalah penting ialah minimnya perhatian orang tua terhadap siswa sehingga motivasi belajar mereka kurang.

Untuk melakukan tindak lanjut, setelah melakukan prates, siswa diberi perlakuan agar ada peningkatan dalam mencurahkan gagasannya melalui tulisan serta benar dalam menata tulisan secara sistematis. Adapun perlakuan itu adalah berikut ini.

1) Siswa diberi kesempatan untuk banyak menulis, misalnya kata dan kalimat dalam penempatan huruf, ukuran kemiringan, dan tanda baca hendaknya diperhatikan.

2) Menciptakan suasana kelas yang menggemari menulis melalui interaksi kooperatif dan menyelesaikan pekerjaan-pekerjaan menulis.

3) Siswa diberi kesempatan dan kebebasan untuk memilih topik yang hendak ditulis.
4) Siswa diberi model pembelajaran untuk melanjutkan cerita.

5) Siswa diberi motivasi secara bertahap, agar berani mengekspresikan perasaan dan pikirannya. Sebelum penilaiandiarahkan kepada ide dan teknik penulisan, terlebih dahulu diarahkan kepada pemakaian huruf capital dan penggunaan tanda baca.

6) Siswa diberi tugas untuk melengkapi kalimat, karena metode ini sangat bermanfaat.

7) Siswa diberi tugas untuk menggabungkan berbagai kalimat.

Menulis beberapa kalimat yang terpisah-pisah tetapi kalimat tersebut dapat disusun menjadi suatu cerita. Selanjutnya, siswa diminta untuk menyusun kalimat-kalimat tersebut menjadi suatu cerita yang logis dan sistematis.

\section{E. SIMPULAN}

Di dalam penyusunan penelitian ini disadari masih harus membutuhkan waktu yang panjang untuk dapat membuat simpulan yang sempurna. Simpulan yang tersusun dalam penelitian ini hanyalah merupakan sebagian kecil dari sebuah simpulan yang utuh untuk menghasilkan sebuah penelitian yang akurat. Namun, penelitian ini akan menjadi sebuah motivasi untuk melakukan banyak hal bagi 
perkembangan dunia pendidikan,khususnya yang berhubungan dengan keterampilan menulis.

Kesulitan belajar secara umum dapatdikemukakan beberapa kriteria yakni: (1) kemungkinan adanya disfungsi otak; (2) kesulitan dalam tugas-tugas akademik; (3) prestasi belajar yang rendah jauh di bawahkapasitas inteligensi yang dimiliki; dan (4) tidak memasukkan sebab-sebab lain sepertikarena

\section{DAFTAR PUSTAKA}

Abdurrahman, Mulyono. 2003. Pendidikan Bagi Anak Berkesulitan Belajar. Jakarta: Rineka Cipta.

Akhdiah, S.,S. Ridwan, dan M.C. Arsyad. 1986. Pembinaan Kemampuan Menulis Bahasa Indonesia. Jakarta: Erlangga.

Djuanda, Dadan, Noi Resmini, dan Dian Indihadi.2006.

Pembinaan dan

Pengembangan Pembelajaran Bahasa dan Sastra Indonesia. Bandung: UPI PRESS.

Keraf, Gorys. 1994. Komposisi. Flores: Nusa Indah.

Nurgiyantoro, Burhan. 2001.

Penilaian dalam Pengajaran Bahasa dan Sastra. Yogyakarta: IKAPI.

Sukardi. 2003. Metodologi Penelitian Pendidikan:

Kompetensi dan Praktiknya. Yogyakarta: Bumi Aksara. tunagrahita, gangguan emosional, hambatan sensoris, ketidaktepatanpembelajaran, atau karena kemiskinanbudaya (Abdurrahman, 2003:14).

Berdasarkan pernyataan di atas, dalam penelitian ini siswa mengalami kesulitan dalam tugastugas akademik, khususnya mata pelajaran bahasa Indonesia. Berdasarkan data yang ada, diambil dari hasil tes kemampuan dasar (TKD).

Tarigan, H.G. 1987. Pengajaran Wacana. Bandung: Angkasa.

Tompkins, Gail E. 1994. Teaching Balancing Process and Product. New York: Mac Millan College Publisher.

Tompkins, Gail E \& Kenneth Hoskisson. 1991. Language Arts: Content and Teaching Strategies. New York: Mac Millan Publishing Company.

Yin, Robert K. 2002. Studi Kasus: Desain \& Metode. Jakarta: PT Rajagrafindo Persada. 